УДК 66.096.5

\title{
МАТЕМАТИЧНЕ МОДЕЛЮВАННЯ ТЕМПЕРАТУРНОГО ПОЛЯ В АПАРАТІ 3 ПСЕВДОЗРІДЖЕНИМ ШАРОМ
}

\author{
Любека А. ${ }^{1}$, Корнієнко Я. ${ }^{2}$ \\ 1,2 - Національний технічний університет України \\ "Київський політехнічний інститут імені Ігоря Сікорського" \\ ORCID: ${ }^{2}$ http://orcid.org/0000-0002-3031-6212 \\ E-mail: ${ }^{1}$ Andrelyubeka@gmail.com, ${ }^{2}$ che@kpi.ua \\ Copyright (C) 2018 by author and the journal “Automation technologies and business - processes. \\ This work is licensed under the Creative Commons Attribution International License (CC BY). \\ http://creativecommons.org/licanses/by/4.0
}

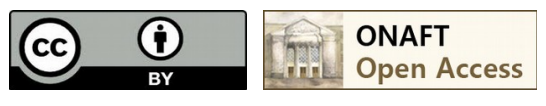

DOI: $10.15673 / a t b p . v 10 i 4.1226$

Анотація: Авторами наведенні результати експериментальних досліджень процесів гранулоутворення складних гетерогенних систем для одержання гуміно-мінеральних композитів з пошаровою структурою. При застосуванні оригінальної конструкції відцентрового механічного диспергатора. Який забезпечив збільшення зони диспергування і підвищив ефективність процесу тепло-масообмінну. Досліди проводились із застосуванням методу струменевопульсаційного псевдозрідження в автоколивальному режимі який створить збільшену зону інтенсивного тепломасообміну всередині апарату. Початковими центрами грануляції були гранули сульфату амонія з домішками гумінових речовин. В середині шару встановлений механічний диспергатор конічного типу. Маса шару в процесі роботи підтримувалась постійною шляхом вивантаження гранульованого продукту. Перепад тиску в шарі вимірювався за допомогою водяного дифманометра, а температура - компютерно-інформаційним комплексом 3 точністю 0,5 ${ }^{\circ} \mathrm{C}$. Розроблена карта треків термопар, по паралельним площиннам, для проведенно дослідження температурного поля в робочій зоні механічного диспергатора. Запропонована математична модель процесу зневоднення та грануляції, що враховує витрати енергї на випаровування вологи при зневодненні та гранулоутворенні, адекватно описує процес при застосуванні струменево-пульсаційного режиму псевдозрідження. Порівняльний аналіз доводить високу збіжність усереднених значення температурного поля та значень отриманих при розрахунку математичної моделі при реалізації струменево-пульсаційного псевдозрідження в автоколивальному режимі з застосованням конічного диспергатора. Визначено температуру при якій реалізується стійкий процес грануляції при підвищеному питомому навантаженні за вологою в апараті в цілому.

Annotation: The authors present the results of experimental studies of granulose formation processes of complex heterogeneous systems for obtaining mineral composites with a layer structure. When applying the original design of a centrifugal mechanical dispersant. Which provided an increase in the dispersion zone and increased the efficiency of the heatmass exchange process. Experiments were carried out with the application of the method of jet-pulsed fluidization in an autoclaving mode, which would create a fusion zone of intense heat-mass transfer inside the apparatus. The initial centers of granulation were granules of ammonium sulfate with impurities of humic substances. In the middle of the layer is a mechanical dispersant conical type. The mass of the layer in the process of operation was maintained constant by unloading the granular product. The pressure difference in the layer was measured with the help of a water difmomanometer, and the temperature was a computer-information system with an accuracy of $0.5^{\circ} \mathrm{C}$. A map of thermo-steam tracks, parallel to the plane, was developed for conducting a study of the temperature field in the working zone of a mechanical dispersant. The mathematical model of the process of dehydration and granulation, which takes into account the energy consumption for moisture evaporation under dehydration and granular formation, is adequately described by the application of the jetpulsating mode of fluidization. The comparative analysis proves the high convergence of the averaged values of the temperature field and the values obtained when calculating the mathematical model for the implementation of jet-pulsed pseudo-fluidization in an autoclaving mode with the use of a conical dispersant. The temperature at which a stable granulation process is implemented at a high specific load on moisture in the apparatus as a whole is determined.

Ключові слова: механічний диспергатор, температурне поле, неоднорідне псевдозрідження, розподілення

Key words: mechanical dispersant, temperature field, inhomogeneous fluidization, distribution 
Вступ

В сучасних умовах широко застосовуються технології для одержання твердих композитів із заданими властивостями які мають відповідну морфологію, що забезпечує рівномірне розподілення мінеральних та органічних компонентів по всьому об’єму твердої частинки. На думку авторів [1] в залежності від способу введення робочого розчину, властивостей компонентів та інтенсивності теплообмінних процесів можна одержати тверді частинки із щільною, пористою, «малиноподібною» або тороподібною структурою. Ефективність таких процесів визначається коефіцієнтом гранулоутворення, який показує частку сухих речовин які надходять в апарат з робочим розчином і трансформуються в гранульований продукт. Цей параметр визначається:

- гідродинамічним режимом псевдозрідження який забезпечує ефективне протікання тепло-масообмінних процесів

- способом введення рідкої фази (гомогенної або гетерогенної) який по суті визначає механізм гранулоутворення.

\section{Огляд літературних джерел}

Широкий діапазон властивостей компонентів в рідкій фазі, реологічні та фізико-хімічні властивості визначають різноманіття способів та конструкцій диспергаторів [1-3].

В останні роки в сільскогосподарському виробництві почали впровадження принципів сталого розвитку щодо раціонального землекористування з одночасним покращенням якості продуктивної частини врожаю тому актуальним науково-технічним завданням стало створення органо - мінеральних добрив нового покоління які містили окрім традиційних мінеральних компонентів, стимулюючі гумінові речовини та інші мікроелементи. Тобто в якості сировини використати відходи хімічної та харчової промисловості, що містять поживні та стимулюючі речовини.

Згідно [4] до водних розчинів сульфату амонію, що утворюється при виробництві капролактаму додають гумінові речовини та інші поживні речовини зокрема кістяне борошно. Складну гетерогенну систему подають на грануляцію в апарат 3 псевдозрідженим шаром для одержання гранульованого продукту з пошаровою структурою. Гранульований продукт повинен мати сфероподібну форму з розмірами $1,5 \div 4,5$ мм 3 рівномірним розподілом по всьому об'ємі мінеральних та органічних речовин. Реалізація таких процесів визначається способом введення рідкої фази до апарату.

В роботах [5-9] наведені різні способи подачі однорідної рідкої фази за допомогою різного типу форсунок розташованих над або у шарі зернистого матеріалу. Проте такий процес гранулоутворення $\epsilon$ стохастичним в якому частіше реалізується агломераційний механізм і тому використовується при зневодненні моносистем. Аналогічний результат досягається при застосування механічних високошвидкісних диспергаторів які встановлюються над шаром зернистого матеріалу [10].

Для забезпечення пошарового механізму гранулоутворення в багатьох випадках застосовують «Wurster» технологію, яка полягає у розташуванні в апараті з псевдозрідженим шаром вертикальних труб через які здійснюється направлена циркуляція зернистого матеріалу в режимі пневмотранспорту.

В нижній частині труби коаксіально розташована форсунка для розпилення рідкої фази. На думку авторів [10] реологічні властивості такої дисперсії дещо погіршується, це негативно впливає на стійкість процесу. Тому для забезпечення заданої продуктивності по рідкій фазі число таких систем збільшується. В реальних умовах це ускладнює контроль за роботою окремих блоків диспергування, а для введення гетерогенних систем взагалі $є$ неприйнятною. Окрім того, при такому способі введення рідкої фази суттєво зростає локальний ризик перезволоження твердих частинок, тому що концентрація твердих частинок у висхідному вертикальному потоці в режимі пневмотранспорту є мінімальною (порозність $\varepsilon \geq 0,8$ ).

Окрім того в таких апаратах має місце недостатня інтенсивність перемішування, а отже не повне використання існуючої поверхні зернистого матеріалу в процесах тепло-масообміну.

\section{Основна частина}

Досліди процесу грануляції проводились в апараті, що має форму паралелпіпеда 3 розмірами АхВхН = 0,3х0,11x1,2 спорядженого газорозподільчим пристроєм в нижній частині та встановленого розподільника в надмірному просторі, до якої підводився нагрітий до температури $190{ }^{\circ} \mathrm{C}$ газовий теплоносій та відбувалася подача робочого розчину, витрати якого регулювались для підтримування температури в шарі до $95 \pm 3{ }^{\circ} \mathrm{C}$.

Висота псевдозрідженого шару становила $\mathrm{H}_{0}=0,320 \mathrm{H}_{\mathrm{m}}$ і визначалась експериментально з умов масообмінну.

Рідка фаза водилась механічним диспергатором конічної конструкції, розташований по центру камери гранулятора, на висоті 0,68 $\mathrm{H}_{0}$.

В якості початкових центрів грануляції використовувались сфероподібні гранули сульфату амонія 3 домішком гумінових речовин з еквівалентним діаметром 1,5 мм. До апарату подавався 40\% водяний розчин сульфату амонія, що містить $1 \%$ гумінових речовин.

Температура теплоносія на вході до апарату $\mathrm{T}_{\mathrm{вx}}=190^{\circ} \mathrm{C}$ температура шару в характерній точці $\mathrm{X}=250, \mathrm{Y}=0, \mathrm{Z}=$ 220 за показниками якої проводились регулювання витрат робочого розчину $\mathrm{T}_{ш}=95 \pm 1{ }^{\circ} \mathrm{C}$. 
Організація процесу при струменево пульсаційному псевдозідженні в автоколивальному режимі наведена на рисунку 1 а.

Проведені дослідження [11] показали, в робочому режимі струменево пульсаційного псевдозрідженні в апараті рисунок 1а, можна виділити 3 зони з точки зору гідродинаміки.

I - зона низхідного руху зернистого матеріалу в яку завдяки асиметричному введенню теплоносія (зріджуючого агенту) відбувається переміщення зернистого матеріалу внаслідок інерційного винесення із зони II і III у верхній частині зони I. Порозність шару в цій зоні практично $€$ сталою $\varepsilon_{\mathrm{I}}=\varepsilon_{0}=0,4$, тому що висота шару в цей момент збільшується в $(1,7 \div 2) \mathrm{H}_{0}$.

II - межова зона в якій відбувається 3D перемішування зернистого матеріалу внаслідок руху внаслідок руху газових бульбашок та переміщень на їх місце зернистого матеріалу в основному із зони I. Порозність в цій зоні змінюється циклічно $\varepsilon_{\text {II }}=0,45 \rightarrow 0,68 \rightarrow 0,45$. В середині цієї зони на висот; $0,45 \mathrm{H}_{0}$ від поверхні ГРП розташований механічний диспергатор, конічного типу з розмірами $D_{6}=80$ мм, $D_{\mathrm{M}}=40$ мм та довжиною 47 мм.

III - в цій зоні відбувається активне об’єднання газових струменів, що виходять з ГРП і призводить до утворення газової бульбашки в момент початку руху у вертикальному напрямку її об’єм практично повністю заповнює перетин зони III, що призводить до інерційного винесення значної кількості зернистого матеріалу в надшаровий простір, при взаємодії із вставкою 4, переміщується в зону I. Таким чином в зоні III утворюється активний висхідний рух зернистого матеріалу, який характеризується циклічною зміною порозності $\varepsilon_{\text {III }}=0,45 \div 0,75$. Висота вертикального факелу $\mathrm{Y}_{\phi}=80$ мм, яка з урахуванням висоти точки введення $\Delta=40$ мм [11] Модель руху сфероподібної гранули на внутрішній поверхні конічного диспергатора наведені на рисунок $1 б$.

Рідка фаза при подачі через трубку 2 розподіляються під дією відцентрової сили у вигляді плівки по внутрішній поверхні диспергатора, яка частково при потраплянні до отворів проходить на зовнішню поверхню диспергатора та розпилюється в зовнішню зону зрошення 3.3, рисунок 16. Диспергатор знаходиться в середині псевдозрідженого шару і тому зернистий матеріал заповнює частину диспергатора який обертається. При цьому гранули які безпосередньо контактують із внутрішньою поверхнею диспергатора частково поглинають рідку фазу і під дією відцентрової сили виводяться з чаші диспергатора в горизонтальному напряму.

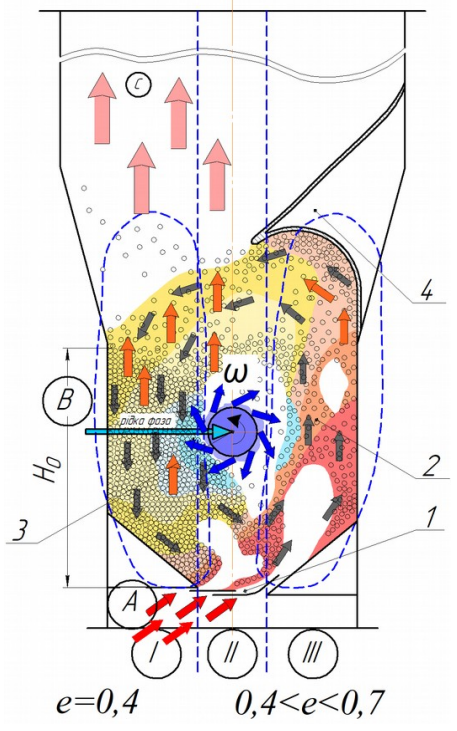

а) Схема взаємодії газового суцільного середовища із зернистим матеріалом

1 - газорозподільчий пристрій, 2 - камера гранулятора, 3 - механічний диспергатор, 4 направляюча вставка [11]

A - подача нагрітого теплоносія, В - подача рідкої фази до диспергатора,

C - відведення відпрацьованого теплоносія із псевдозрідженого шару

$\mathrm{H}_{0}$ - висота початкового нерухомого шару в апараті

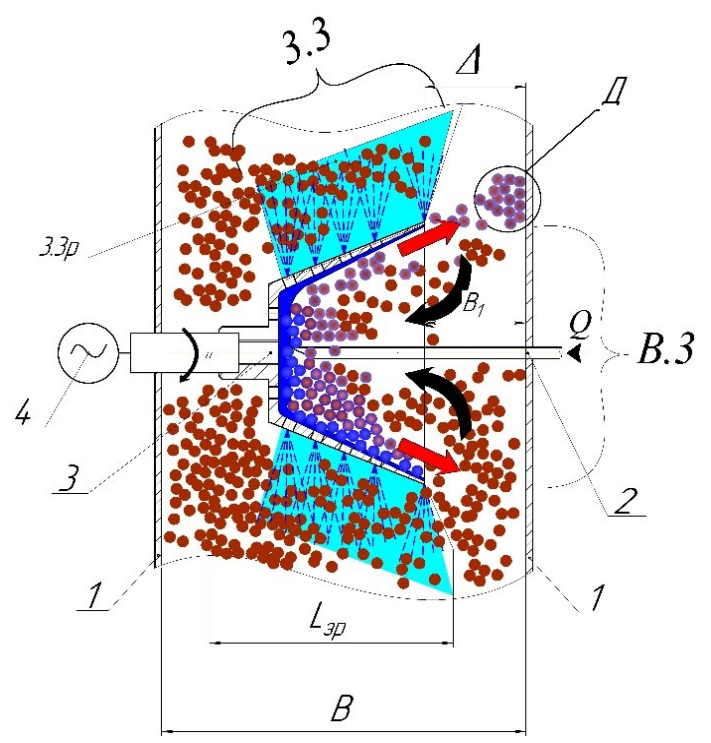

б) Модель руху зернистого матеріалу в зоні зрошення

1 - передня та задня стінка апарату, 2 - трубка подачі рідкої фази, 3 - механічний диспергатор, 3.3 зовнішня зона зрошення механічного диспергатора,

В3 - зона циркуляції зернистого матеріалу у внутрішній зоні диспергатора.

Рис. 1 - Схема взаємодії газового суцільного середовища із зернистим матеріалом 
Досліди проводились при зневодненні 40\% (мас) розчину сульфату із вмістом гумінових речовин до $2 \%$ по відношенню до сухих речовин.

Кінетичні характеристики процесу гранулоутворення із застосуванням конічного диспергатора 3 відбійними кільцями [10] наведено на рисунок 2 - 6 показують позитивну динаміку роста De рисунок 2 та послідовний обмін між фракціями рисунок 3, що свідчить про відсутність агломератів. Динаміка зміни температури теплоносія на вході до апарату та шарі , рисунок 4, характеризує стабілізацію теплового режиму апарата. При цьому досягнуті робочі значення питомого навантаження за вологою $\mathrm{a}_{\mathrm{f}}=0,58{ }^{\frac{\mathrm{kr} \mathrm{s} \text { гл. }}{\mathrm{n}^{2} \text { год }}}$, що в $1,5 \div 1,9$ перевищує цей показник для дискових диспергаторів рисунок 5. При цьому коефіцієнт гранулоутворення $\varphi \geq 90 \%$ рисунок 6 , а гранульований продукт відповідає існуючим вимогам.

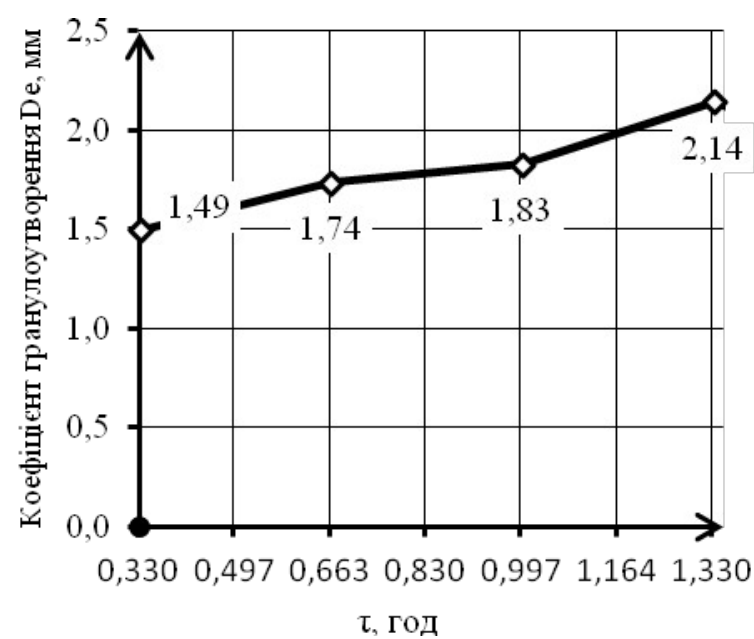

Рис. 2 - Динаміка зміни еквівалентного діаметра гранул

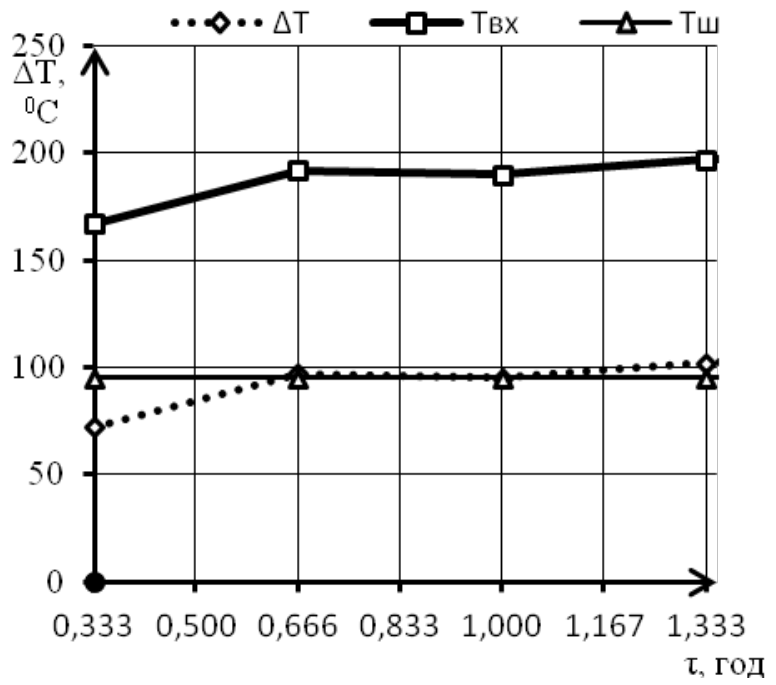

Рис. 4 - Динаміка зміни температури теплоносія на вході та в камері апарата

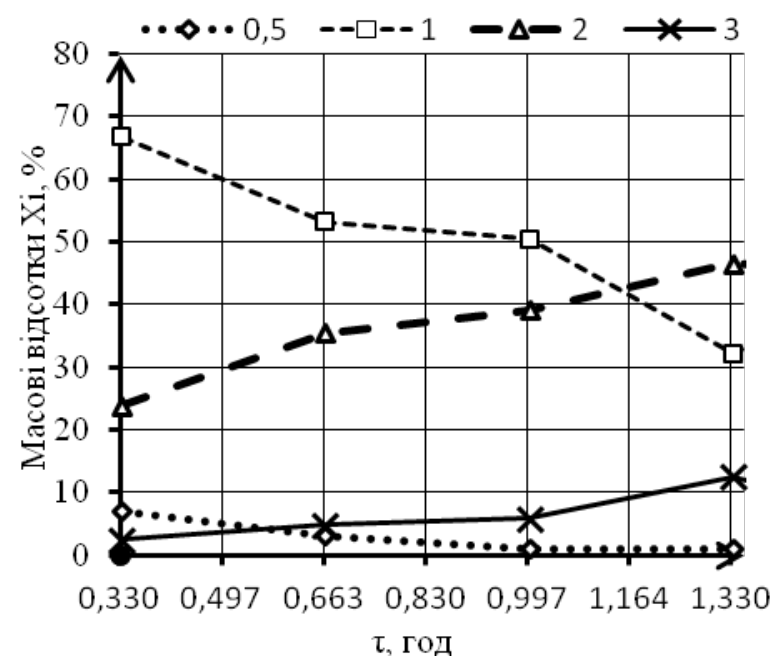

Рис. 3 - Динаміка зміни масових відсотків окремих фракцій із розміром гранул: +0,5 мм; +1,0 мм; +2,0 мм; +3,0 мм; +4,0 мм.

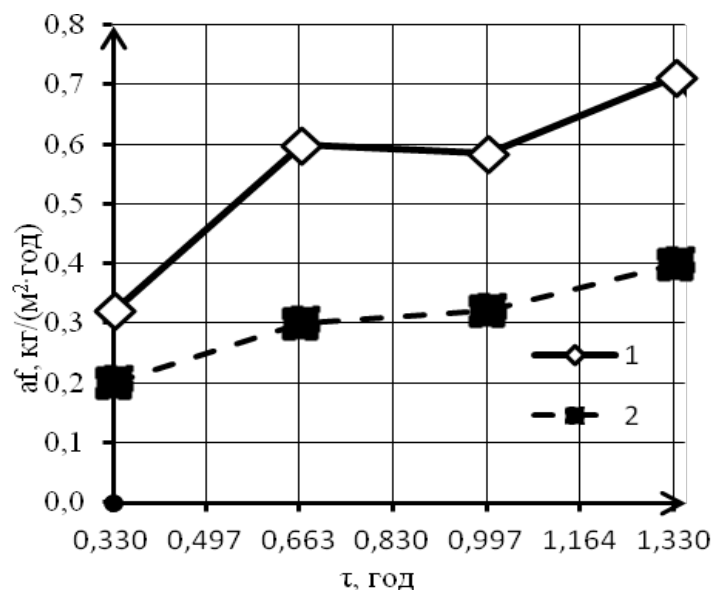

1-конічний диспергатор

2-дисковий диспергатор

Рис. 5 - Динаміка зміни питомого навантаження поверхні шару за вологою 


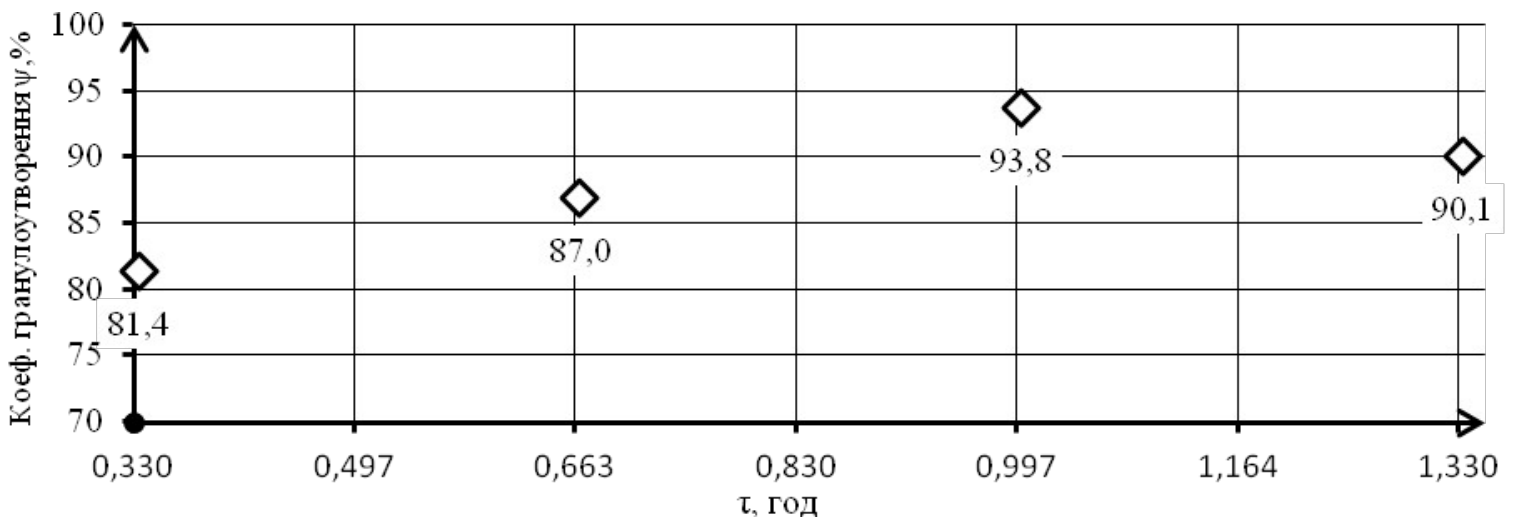

Рис. 6 - Динаміка зміни коефіцієнта гранулоутворення

Для вимірювання поля температур робоча камера гранулятора розбита умовними площинами рисунок 7, в яких розміщені треки термопар .

ПЛ $1(\mathrm{X}=50 ; \mathrm{Y}=0-110 ; \mathrm{Z}=0 \div 500)$

ПЛ $2(\mathrm{X}=150 ; \mathrm{Y}=0-110 ; \mathrm{Z}=0 \div 500)$

ПЛ $3(\mathrm{X}=200 ; \mathrm{Y}=0-110 ; \mathrm{Z}=0 \div 500)$

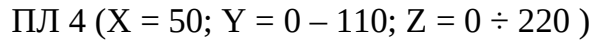

Результати вимірювання температурного поля в полі диспергатора по ширині на висоті Z = 220 (вісь обертання дисператора) в низхідному потоці

рисунок $8 \frac{d T}{d y}=-0,525 \frac{\text { град }}{\mathrm{mm}}$. Спостерігається мінімальне значення $71^{\circ} \mathrm{C}$ на крайці диспергатора 3 наступним поверненням температури в дисперсному середовищі до $94{ }^{\circ} \mathrm{C}$ на відстань $\Delta \mathrm{Y}_{3}=30$ мм, рисунок 8.

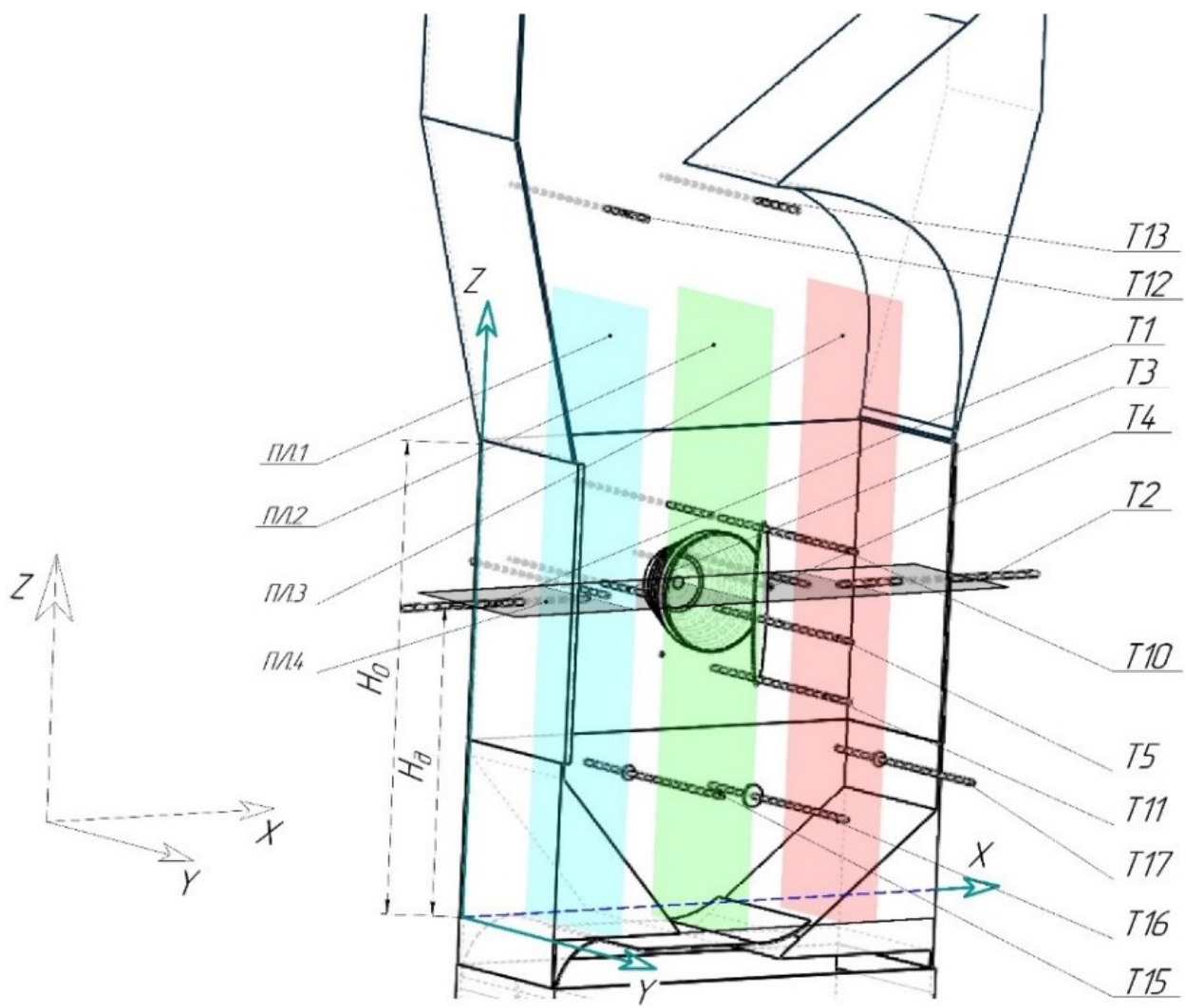

Рис. 7 - Схема розміщення треків термопар в камері гранулятора 
Динамічним зростанням $\frac{d \tau}{d y}=+1,5 \frac{\text { гpaд }}{\mathrm{mm}}$ рисунок 8 у висхідному потоці градієнт вздовж робочої зони трохи менший $\frac{d \tau}{d y}=-0,275 \frac{\text { грап }}{\text { мм }}$, а в фронтальній зоні перед крайкою диспергатора $\frac{d \tau}{d y}=+0,7 \frac{\text { грап }}{\text { мм }}$ рисунок 8.

Зміна температури Т4 в треку розташованому в ПЛ $4 \mathrm{X}=200 \mathrm{мm}, \mathrm{Z}=220 \mathrm{мм}$

$0 \leq \mathrm{X} \leq 110$ рисунок 9 показує, що в зоні зрошення температура зменшується по довжині диспергування від 93 до $75^{\circ} \mathrm{C}$ на бічній крайці диспергатора зони релаксації $\Delta \mathrm{Y}_{4}$ становить 10 мм, що в три рази менше ніж у попередньому випадку.

Вимірювання температури в ПЛ 2 треку розташованого на $Z=270$ мм, наведено на рисунок 10 Характер зміни температур по довжині зони диспергування аналогічний попереднім із збільшеною зоною релаксації $\Delta \mathrm{Y}_{10}$ до 40 мм. Це пояснюється інтенсивним переміщенням зволожених гранул у вертикальному напрямку.

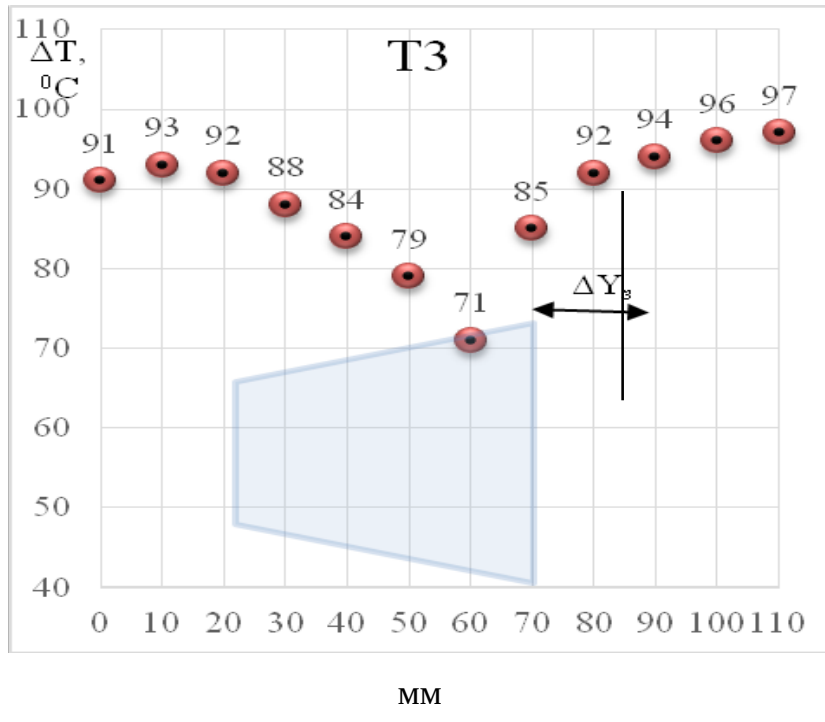

Рис. 8 - Зміна температури в площина на межі зони I і II при $X=100$ мм, $0 \leq \mathrm{Y} \leq 110$ мM, $\mathrm{Z}=220$ мм, Т3

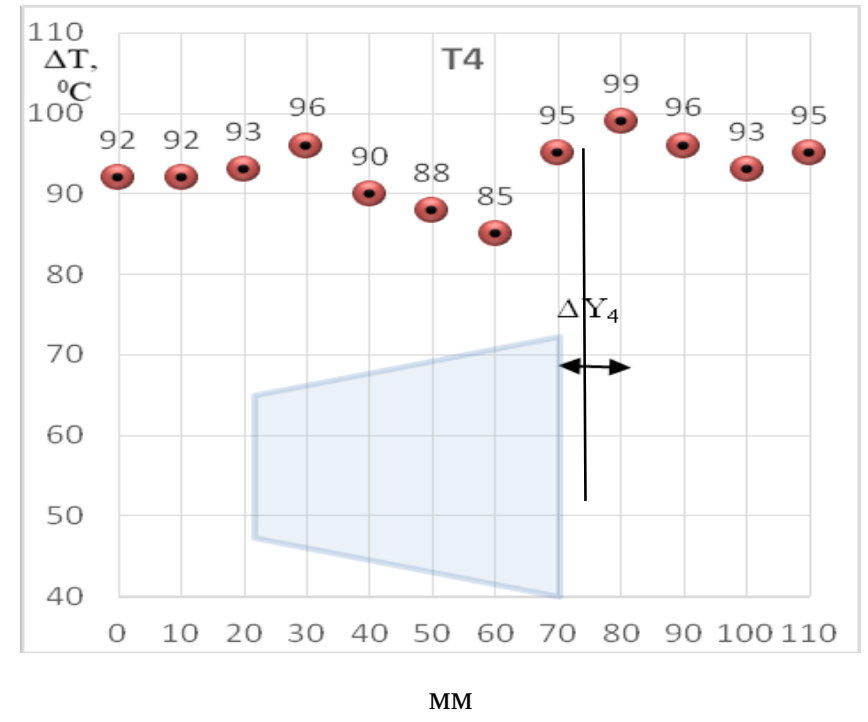

Рис. 9 - Зміна темпера $:$, $\ldots$, висхідній площині А при $X=200$ мм, $0 \leq Y \leq 110$ мм, $Z=220$ мм, T4

Зміна температур в треку термопари $\mathrm{T} 11$ розташованій в ПЛ 2 на висоті $\mathrm{Z}=170$ мм який розташований на 10 мм від більшої крайки диспергатора наведений на рисунок 11.

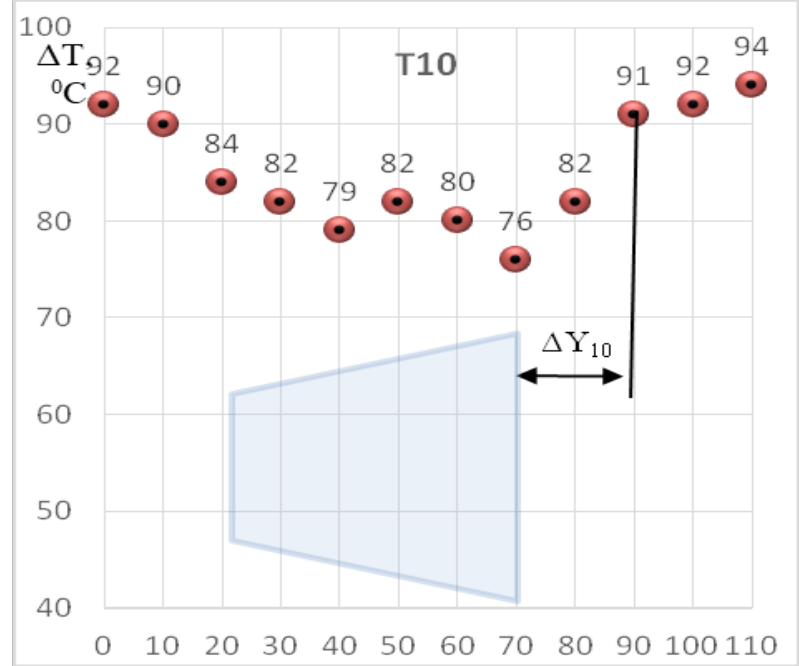

MM

Рис. 10 - Зміна темпераг, , площина А при $X=150$ мм, $0 \leq Y \leq 110$ мм, $Z=270$ MM, T10

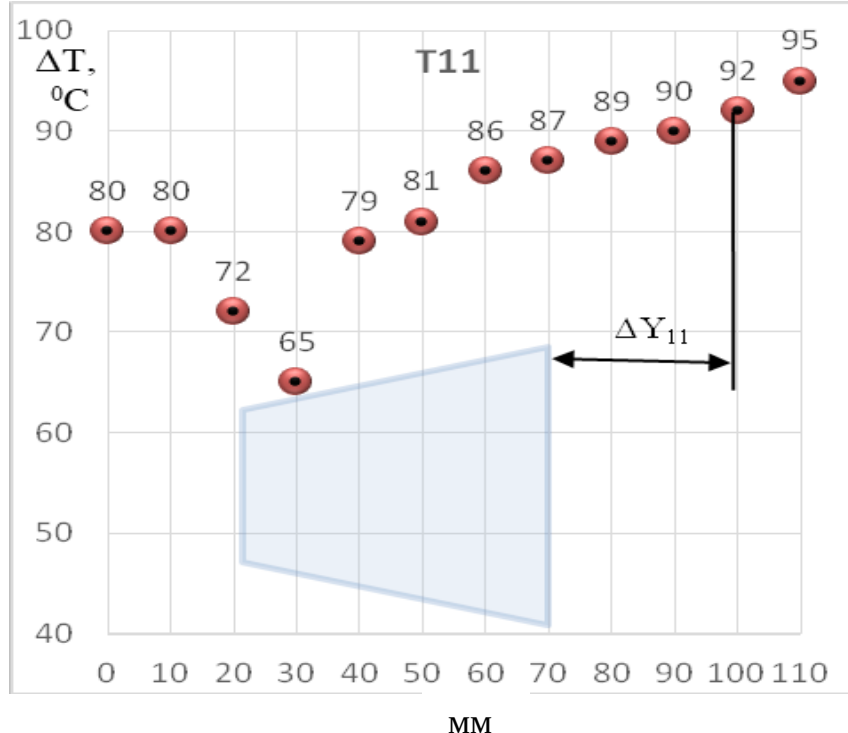

Рис. 11 - Зміна тем......, ри в ПЛ 2 під диспергатором, при $X=150$ мм, $\mathbf{0} \leq \mathrm{Y} \leq 110$ мм, $\mathrm{Z}=170$ мм, 
Діапазон зміни температур до крайки диспергатора, що знаходиться на рівні 90 - $80{ }^{\circ} \mathrm{C}$ рисунок 11 , по довжині диспергатора змінюється від 87 до $65^{\circ} \mathrm{C}$ з наступним підвищенням до $80{ }^{\circ} \mathrm{C}$. Ці значення дещо нижчі від температури в характеристичній точці і підтверджують вплив зони диспергування. Активний гідродинамічний режим зумовлює відсутність зони релаксації перед більшою крайкою диспергатора.
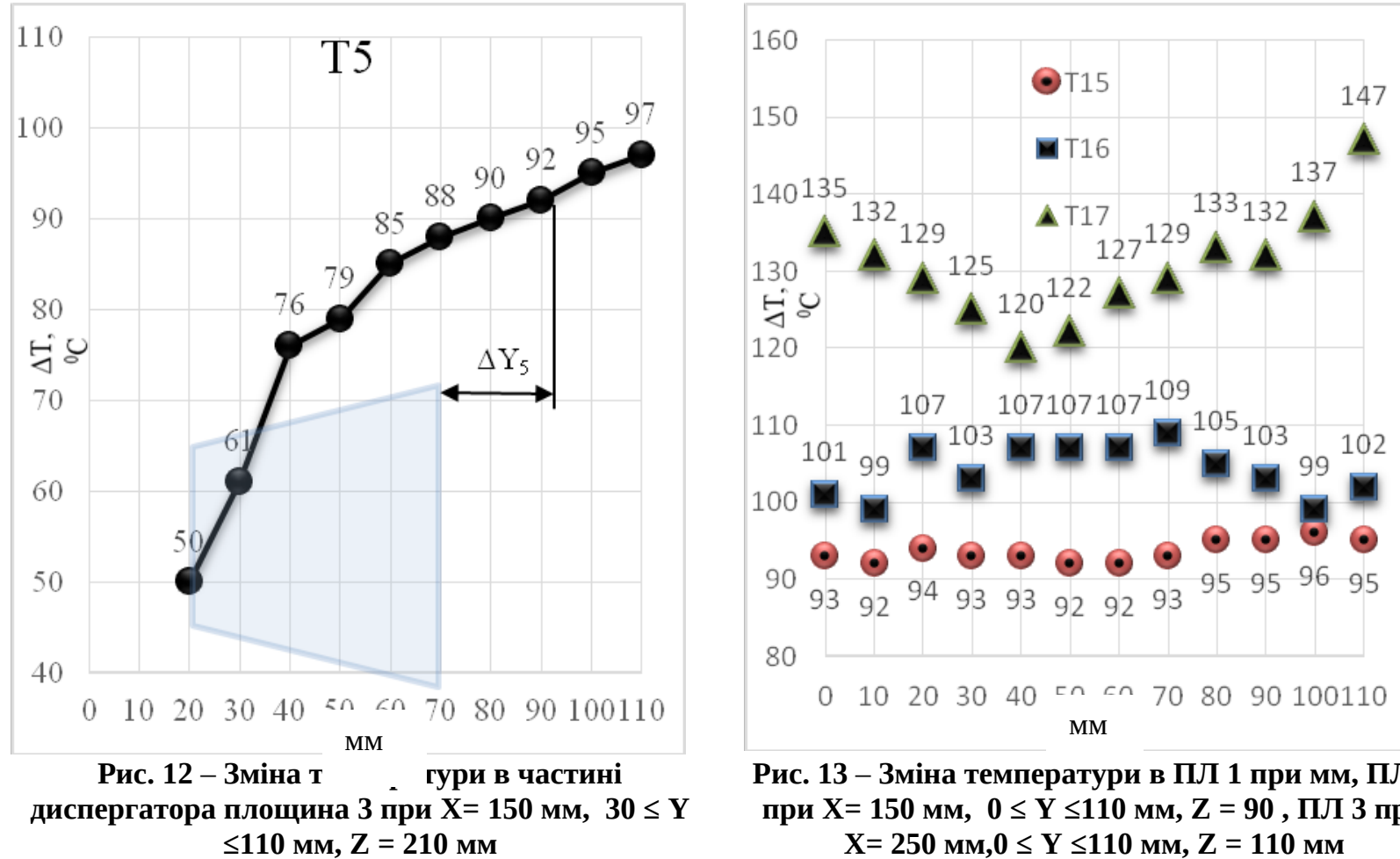

Рис. 13 - Зміна температури в ПЛ 1 при мм, ПЛ 2 при $X=150$ мм, $0 \leq \mathrm{Y} \leq 110$ мм, $Z=90$, ПЛ 3 при $\mathrm{X}=250$ мм,0 $\leq \mathrm{Y} \leq 110$ мм, $\mathrm{Z}=110$ мм

Наявність направленого циркуляційного руху з зони диспергатора підтверджує характер зміни температури в треку, що проходить по вертикальній площині на 10 мм нижче вісі обертання Т5, рисунок 12. Так, мінімальна значення температури в площинні введення рідкої фази $50{ }^{\circ} \mathrm{C}$, а на виході $85{ }^{\circ} \mathrm{C}$, рисунок 15 тобто градієнт становить

$\frac{d T_{5}}{d y}=1,375 \frac{\mathrm{rpan}}{\mathrm{mm}}$

зона релаксації підвищено до $95{ }^{\circ} \mathrm{C} \Delta \mathrm{Y}_{5}=40$ мм. При цьому розмір зони релаксації перед більшою

крайкою диспергатора в нижній вісі обертання досягає максимальних значень $\Delta \mathrm{Y}_{5}=40$ мм. Градієнт температур в середині диспергатора $\frac{d T_{5}}{d z}=8,75 \frac{\text { грап }}{\mathrm{mm}}$.

Цей параметр разом з велечиною $\Delta \mathrm{Y}_{5}$ свідчить про потужний струмінь зволожених частинок, які під дією відцентрової сили відводяться із чаші диспергатора.

На рисунку 13 наведені результати вимірювання температур в горизонтальних площинах розташованих відповідно:

Т $15(\mathrm{X}=50$ мм, $0 \leq \mathrm{Y} \leq 110 \mathrm{мм}, \mathrm{Z}=110)$ ПЛ 1

Т $16(X=150$ мм, $0 \leq \mathrm{Y} \leq 110$ мм, $Z=90)$ ПЛ 2

Т $17(\mathrm{X}=250$ мм, $0 \leq \mathrm{Y} \leq 110$ мм, $\mathrm{Z}=110)$ ПЛ 3

Так на висоті $Z=110$ мм в ПЛ 1, низхідний рух зони I температура по всій глибині зони $0 \leq \mathrm{Y} \leq 110$ знаходиться в межах $95 \div 93{ }^{\circ} \mathrm{C}$ T15, рисунок 13 . Значення температур вимірюються по середині зони II, знаходиться на $5 \div 10{ }^{\circ} \mathrm{C}$ вище ніж у ПЛ 1 в діапазоні значень $99 \div 107{ }^{\circ} \mathrm{C}$, Т16, рисунок 13 в якій відбувається спрямований рух нагрітого теплоносія.

На рисунок 14 наведена експериментально визначена зміна температур по висоті апарату для пл.1,2,3 та розрахована за модель.

Висота шару при якій температура дисперсійного середовища стабілізується $95 \pm 3{ }^{\circ} \mathrm{C}$ для пл 1 і 2 досягається на висоті Z = 110 мм, а для площини $3 \Delta \mathrm{Z}=200$ мм це пояснюється струменево пульсаційним псевдозрідженням в автоколивальному режимі рисунок 14. Зниження середньої температури шару при $Z=200$ мм для ПЛ 2 пов’язане із зоною введення рідкої фази із застосуванням конічного диспергатора яке завдяки інтенсивному об'ємному перемішуванню призводить до вирівнюванню температури в порвнянні з іншими площинами на висоті Z = 300 мм. 
Таким чином в околі диспергатора утворюється зона зрошення у вигляді зрізаного конуса розташованого горизонтально з висотою, що на 20\% перевищує робочу довжину диспергатора та зовнішній діаметр.

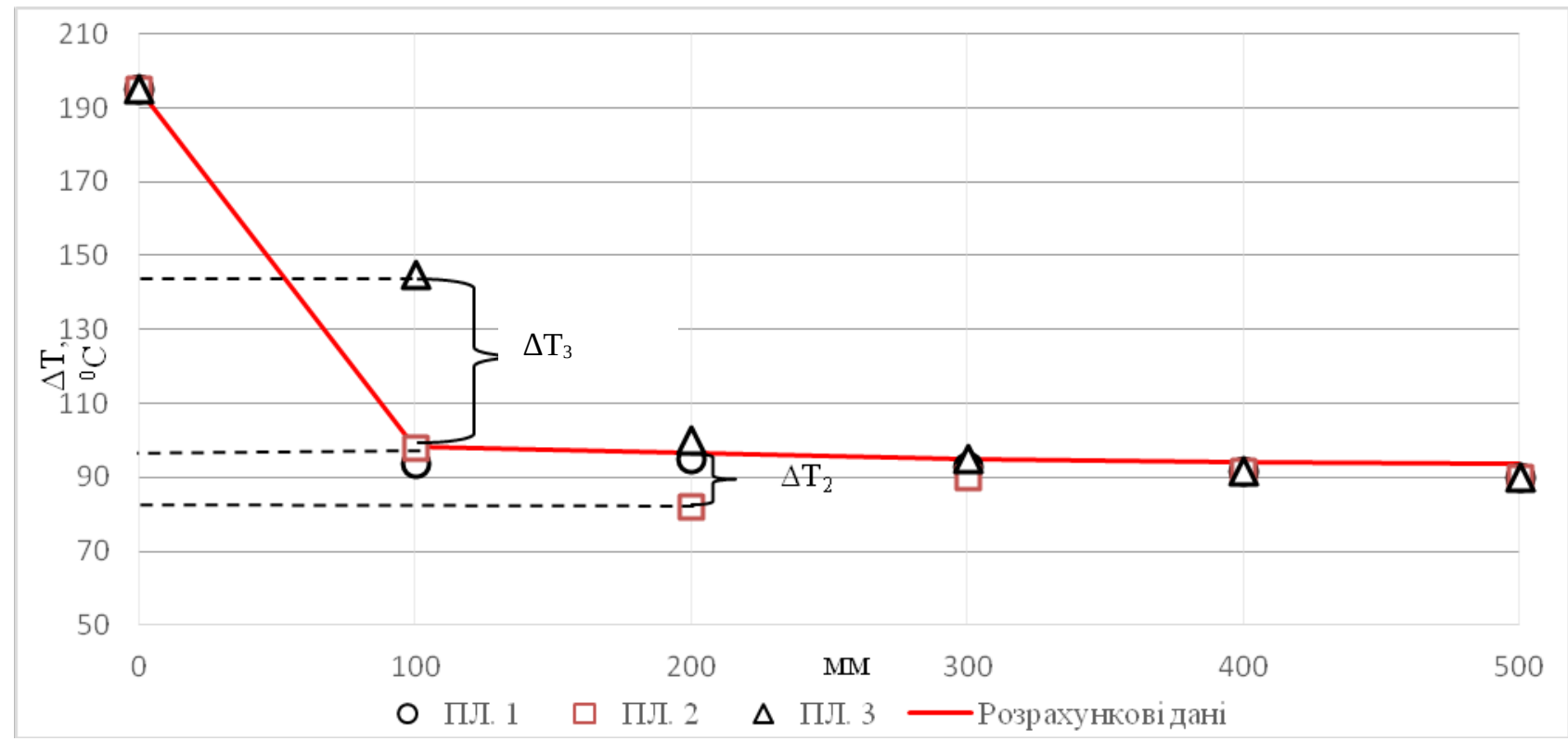

Рис. 14 - Зміна температури теплоносія по висоті апарата в площині

ПЛ. 1(Низхідний рух) X = 50, ПЛ. 2 (центральна площина) X = 150, ПЛ. 3 (Висхідний рух) X = 250 .

Через цю область з частотою 1,6 - 1,8 Гц відбувається інтенсивне переміщення матеріалу внаслідок реалізації струменево-пульсаційного псевдозрідження в автоколивальному режимі, при якому до 45\% маси шару виноситься за межі початкового об’єму шару [12].

Звідки загальний час циклу $\tau_{ц}=1 / \mathrm{F}=0,55 \div 0,625 c$, з якої $2 / 3 \tau_{ц}-$ це загальний час переміщення матеріалу із зони II i III за межі початкового об'єму шару, та ${ }^{\frac{1}{3}} \tau_{ц}-$ час переміщення зернистого матеріалу в тимчасово утворенні пустоти зони II і III [13].

Враховуючи стохастичну природу псевдозрідженого шару максимально можливий час перебування частинок в зоні зрошення досягає ${ }^{\frac{2}{3}} \mathrm{~T}_{ц}=0,42-0,36$ с. в якій температура середовища наближається до температури мокрого термометра, що при наявності розміру в межах $10 \div 250$ мкм зумовлює формування плівки рідини за рахунок дії адгезійно-сорбційних сил.

В основу математичної моделі теплообмінну покладено рівняння авторів [14] яке доповнено витратами енергії на підігрів рідкої фази, яка знаходиться на поверхні гранул у вигляді плівки, та витрати на нагрівання та випаровування розчинника. Тоді рівняння теплового балансу для газового теплоносія записується у вигляді:

Для гранул:

$$
\varepsilon \cdot \rho \cdot C \cdot \frac{\partial T_{\Gamma}}{\partial t}+V_{\Gamma} \cdot \varepsilon \cdot \rho \cdot \frac{\partial T_{\Gamma}}{\partial x}=\varepsilon \cdot a \cdot \frac{\partial^{2} T_{\Gamma}}{\partial y^{2}}-\alpha \cdot F \cdot\left(T_{\Gamma}-T_{p+n}\right)+G_{p} \cdot\left(1-x_{p}\right) \cdot\left(r+C_{n} \cdot T_{p+n}\right)
$$

$$
\begin{aligned}
& (1-\varepsilon) \cdot \rho \cdot C \cdot \frac{\partial T_{p+n}}{\partial t}-V_{p+n} \cdot(1-\varepsilon) \cdot \rho \cdot \frac{\partial T_{p+n}}{\partial x}=\alpha \cdot F \cdot\left(T_{\Gamma}-T_{p+n}\right)- \\
& -G_{p} \cdot\left(1-x_{p}\right) \cdot\left(r+C_{n} \cdot T_{p+n}\right)+G_{p} \cdot x_{p} \cdot q ;
\end{aligned}
$$

де $\varepsilon$ - порозність шару (частка газу)

$\rho_{\text {г }}-$ густина газу, $k 2 / M^{3}$

$\rho_{\text {т }}$ - густина гранул, $\mathrm{kz}^{2} \mathrm{M}^{3}$

$w_{2}$ - швидкість газу, $\stackrel{ }{c}$;

$\mathrm{C}_{г}$ - теплоємність газу, $\frac{\mathrm{KД} \cdot \mathrm{K}}{\mathrm{kr}}$ 
$\lambda_{г}-$ теплопровідність газу, $\frac{\mathrm{B} \text { т }}{\mathrm{kr} \cdot \mathrm{K}}$

F - питома поверхня гранул в шарі на заданій висоті, $\mathrm{m}^{2} / \mathrm{m}^{3}$

$F=\frac{6\left(1-\varepsilon_{0}\right)}{d_{e}}, d_{\theta}=\frac{1}{d_{e}=\frac{1}{\sum \frac{x_{i}}{d_{i}}}}$

$\mathrm{d}_{e}$ - еквівалентий діаметр частинок в шарі, мм

$\mathrm{x}_{\mathrm{i}}$ - масова частина $\mathrm{i}$ - тої фракції,

$\mathrm{d}_{i}-$ середній розмір і - тої фракції, мм

$\mathrm{G}_{\mathrm{p}}$ - питоме масове навантаження шару зернистого матеріалу, $\frac{\mathrm{kr}}{\mathrm{cm}}$

$\mathrm{X}_{\mathrm{p}}$ - концентрація сухих речовин в розчині, що подається до гранулятора, \% (масс)

$\mathrm{T}_{\mathrm{r}}, \mathrm{T}_{ш}$ - температура теплоносія на вході до гранулятора і температура в шарі, ${ }^{\circ} \mathrm{C}$

$\mathrm{T}_{\text {г }}$ - температура теплоносія, K;

$\mathrm{C}_{\mathrm{p}}$ - теплоємність робочого розчину, що подається до апарату, $\frac{\text { r. град }}{\mathrm{kж}}$

q- ефективна теплота кристалізації, $\frac{\text { кг-грал }}{\mathrm{k} \text {-гж }}$

$\mathrm{r}$ - питома теплота пароутворення, $\frac{\mathrm{kдx}}{\mathrm{kr}}$

$w_{m}$ - швидкість руху твердих частинок, $\frac{\text { m }}{\mathrm{c}}$;

$\alpha-$ коефіцієнт тепловіддачі від газу до поверхні гранул, $\frac{\mathrm{B} т}{\mathrm{~m}^{2} \cdot \mathrm{K}}$;

a - коефіцієнт температуропровідності, $\frac{\mathrm{m}^{2}}{\mathrm{c}}$

Порівняння зміну температури розрахованою рисунок 14 за рівнянням (1) з експериментальними дає хорошу збіжність за винятком зони III, в якій застосований струменево-пульсаційний спосіб введення теплоносія.

Так завдяки застосуванню механічного, конічного диспергатора з розширеною зоною диспергування, температура шару в зоні III (висхідна) з $\Delta \mathrm{T}_{3}=40^{\circ} \mathrm{C}$, в порівняння з іншими зонами на висоті розподілення диспергатора досягає значень зони I (низхідної) рисунок 14. Різниця температур $\mathrm{Z}=100 \mathrm{Mм}, \Delta \mathrm{T}_{2}=12{ }^{\circ} \mathrm{C}$, що майже в три рази менше ніж при застосуванні дискового диспергатора. Це дозволяє усунути ризик утворення агломератів внаслідок перезволоження шару в зонні введення рідкої фази.

\section{Висновки}

Запропоновано математична модель дозволяє адекватно описати усереднені значення температурного поля при реалізації струменево-пульсаційного псевдозрідження, 3 застосованням конічного диспергатора та визначити температуру при якій реалізується стійкий процес грануляції $\varphi=90 \%$ та суттєво підвищити питоме навантаження за вологою в апараті в цілому.

\section{Список використаних джерел}

[1] Nandiyanto, A. B. Progress in developing spray-drying methods for the production of controlled morphology particles: From the nanometer to submicrometer size ranges / Okuyama, K //.. Advanced Powder Technology - 2011, 22(1), 1-19. https://doi.org/10.1016/j.apt.2010.09.011

[2] Iskandar F. Production of morphology-controllable porous hyaluronic acid particles using a spray-drying method / Nandiyanto Widiyastuti W., Young L.S., Okuyama K., Gradon L. // Acta Biomaterialia. - 2009. 1034

[3] Widiyastuti W. Simulation and experimental study of spray pyrolysis of polydispersed droplets / W.N. Wang, I.W. Lenggoro, F. Iskandar, K. // Journal of Materials Research. - 2007. Vol.22.4 P. 1888-1898

[4] Kornienko Y. Kinetic laws of the process of obtaining complex humic-organic-mineral fertilizers in the fluidized bed granulator Haidai S., Liubeka A., Martynyuk O. // Ukrainian Food Journal-2016, V.5 (№1), pp. 144-154.

[5] Bang J.H. Applications of ultrasound to the synthesis of nanostructured materials / Suslick K.S // Advanced Materials - 2010 V.20 (№1), pp. 1039-1059. 
[6] Iskandar F. Production of morphology-controllable porous hyaluronic acid particles using a spray-drying method / Nandiyanto, Widiyastuti W., Young L.S., Okuyama K., Gradon L. // ～， Acta Biomaterialia -2009, V.5 (№4), pp. 1027-1034.

[7] Iskandar F. Macroporous anatase titania particle: aerosol self-assembly fabrication with photocatalytic performance / Widiyastuti W., Young L.S., Okuyama K., Gradon L. // Chemical Engineering Journal -2009, V.152 (№1), pp. 293296.

[8] Iskandar F. Functional nanostructured silica powders derived from colloidal suspensions by sol spraying / Widiyastuti W., Young L.S., Okuyama K., Gradon L. // Journal of Nanoparticle Research -2001, V.3 (№4), pp. 263-270

[9] Zbicinski I. Advanced experimental analysis of drying kinetics in spray drying / A. Delag, C. Strumillo, J. Adamiec, // Chemical Engineering Journal -2002, V.86 (№1-2), pp. 253-283

[10] Kornienko Y. Influence of mechanical disperator designer parameters on equality of distribution of solution ., Liubeka A., Martynyuk O. // Ukrainian Food Journal-2016, V.7 (№1), pp. 105-119.

[11] Kornienko Y. Kinetic laws of the process of obtaining complex humic-organic-mineral fertilizers in the fluidized bed granulator / Haidai S., Liubeka A., Martynyuk O. // Ukrainian Food Journal-2016, V.5 (№1), pp. 144-154.

[12] Kornienko Y. Non-uniform fluidization in auto-oscillating mode / Haidai S., Kornienko Y. // Ukrainian Food Journal-2016, V.6 (№3), pp. 562-576.

[13] Lyubek A.N. The evaluation efficiency of working mechanical liquid distributor, / Manastyrny M.N., Kornienko Y.N. // Young Scientist -2017, (№11), pp. 6 - 9

[14] Sutkar, V. S . CFD - DEM model for coupled heat and mass transfer in a spout fluidized bed with liquid injection / Deen, N. G., Patil, A. V, Salikov, V., Antonyuk, S., Heinrich, S., \& Kuipers, J. A. M. // CHEMICAL ENGINEERING JOURNAL - 2016, 288, 185-197. https://doi.org/10.1016/j.cej.2015.11.044

\section{References}

[1] Nandiyanto, A. B. (2011) Progress in developing spray-drying methods for the production of controlled morphology particles: From the nanometer to submicrometer size ranges / Okuyama, K //.. Advanced Powder Technology, 22(1), 119. https://doi.org/10.1016/j.apt.2010.09.011

[2] Iskandar F. (2009) Production of morphology-controllable porous hyaluronic acid particles using a spray-drying method / Nandiyanto Widiyastuti W., Young L.S., Okuyama K., Gradon L. // Acta Biomaterialia. P. 1027-1034

[3] Widiyastuti W. (2007) Simulation and experimental study of spray pyrolysis of polydispersed droplets / W.N. Wang, I.W. Lenggoro, F. Iskandar, K. // Journal of Materials Research. Vol.22.4 P. 1888-1898

[4] Kornienko Y. (2016) Kinetic laws of the process of obtaining complex humic-organic-mineral fertilizers in the fluidized bed granulator Haidai S., Liubeka A., Martynyuk O. // Ukrainian Food Journal, V.5 (№1), pp. $144-154$.

[5] Bang J.H. (2010 ) Applications of ultrasound to the synthesis of nanostructured materials / Suslick K.S // Advanced Materials V.20 (№1), pp. 1039-1059.

[6] Iskandar F. (2009) Production of morphology-controllable porous hyaluronic acid particles using a spray-drying method / Nandiyanto, Widiyastuti W., Young L.S., Okuyama K., Gradon L. // Acta Biomaterialia -, V.5 (№4), pp. 10271034.

[7] Iskandar F. (2009)Macroporous anatase titania particle: aerosol self-assembly fabrication with photocatalytic performance / Widiyastuti W., Young L.S., Okuyama K., Gradon L. // Chemical Engineering Journal, V.152 (№1), pp. 293-296.

[8] Iskandar F. (2001) Functional nanostructured silica powders derived from colloidal suspensions by sol spraying / Widiyastuti W., Young L.S., Okuyama K., Gradon L. // Journal of Nanoparticle Research , V.3 (№4), pp. 263-270

[9] Zbicinski I. (2002) Advanced experimental analysis of drying kinetics in spray drying / A. Delag, C. Strumillo, J. Adamiec, // Chemical Engineering Journal, V.86 (№1-2), pp. 253-283

[10] Kornienko Y. (2016) Influence of mechanical disperator designer parameters on equality of distribution of solution ., Liubeka A., Martynyuk O. // Ukrainian Food Journal, V.7 (№1), pp. 105-119.

[11] Kornienko Y. (2016) Kinetic laws of the process of obtaining complex humic-organic-mineral fertilizers in the fluidized bed granulator / Haidai S., Liubeka A., Martynyuk O. // Ukrainian Food Journal, V.5 (№1), pp. 144-154.

[12] Kornienko Y. (2016) Non-uniform fluidization in auto-oscillating mode / Haidai S., Kornienko Y. // Ukrainian Food Journal, V.6 (№3), pp. 562-576.

[13] Lyubek A.N. (2017) The evaluation efficiency of working mechanical liquid distributor, / Manastyrny M.N., Kornienko Y.N. // Young Scientist, (№11), pp. 6 - 9

[14] Sutkar, V. S . (2016) CFD - DEM model for coupled heat and mass transfer in a spout fluidized bed with liquid injection / Deen, N. G., Patil, A. V, Salikov, V., Antonyuk, S., Heinrich, S., \& Kuipers, J. A. M. // CHEMICAL ENGINEERING JOURNAL, 288, 185-197. https://doi.org/10.1016/j.cej.2015.11.044 